
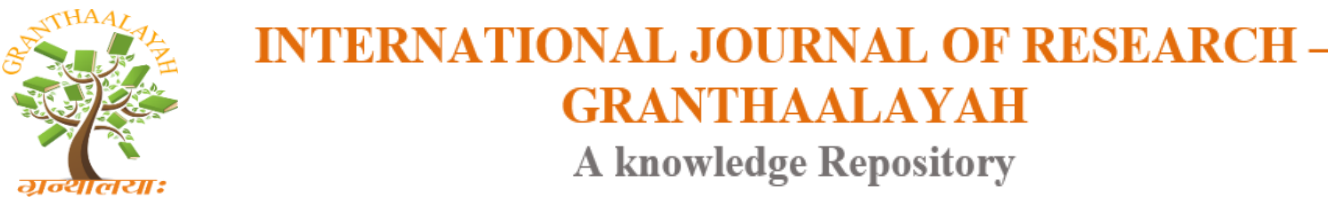

Science

\title{
DETAIL OF PARSING LITHOLOGICAL MEMBERS OF THE TERRAIN AND EMBANKMENT ALONG THE ROUTE OF THE RAILWAY SAMAC \\ - SARAJEVO, CORRIDOR V, SECTION CHAINAGE KM 85 + 000 - 103+500, BOSNIA AND HERZEGOVINA
}

\author{
Nedjo Djuric ${ }^{* 1}$, Dijana Djuric ${ }^{2}$ \\ ${ }^{*} 1,2$ Technical institute Bijeljina, Bosnia and Herzegovina
}

DOI: https://doi.org/10.29121/granthaalayah.v4.i12.2016.2390

\begin{abstract}
Revitalization of the railways is a started project of the European Union, where is necessary for all the tracks of the former Yugoslavia to be revitalized in order to improve their train speed quality up to $120 \mathrm{~km} /$ hour. The railway that passes through the middle of Bosnia and Herzegovina, from north to south, is the Corridor Vc and connects Budapest, that is Central Europe with the Adriatic Sea. The largest part of the railway was revitalized, and researched section is one of several remaining that need to be investigated in detail before revitalized. It is expected its full completion by 2010. During the research of mentioned section, in detail were studied the characteristics of the terrain and the buffer layer of railway along its route. The level of detail was such that it had allocated all the characteristics of lithological members and embankments per chainages.
\end{abstract}

Keywords: Parsing; Lithological Members; Research Works.

Cite This Article: Nedjo Djuric, and Dijana Djuric. (2016). "DETAIL OF PARSING LITHOLOGICAL MEMBERS OF THE TERRAIN AND EMBANKMENT ALONG THE ROUTE OF THE RAILWAY SAMAC - SARAJEVO, CORRIDOR V, SECTION CHAINAGE KM 85 + 000 - 103+500, BOSNIA AND HERZEGOVINA.” International Journal of Research - Granthaalayah, 4(12), 34-40. https://doi.org/10.29121/granthaalayah.v4.i12.2016.2390.

\section{Introduction}

Previously constructed railways in Bosnia and Herzegovina do not meet the regulated norms in the European Union today. Therefore was approached to the improvement of their quality in order to increase the safety of the railway speed up to $120 \mathrm{~km} /$ hour. Investigated section is on the Corridor Vc which connects Central Europe with the Adriatic Sea. To date, the railway is largely revitalized by sections and is expected its full revitalization by 2020 . 
Within the revitalization of the railway is planned a prior study of the current situation, considering that one track was built 60 years ago, and the other 30 years ago. The complexity of the terrain along the route of the railway, the characteristics of the embankment constructed in different time periods, poor track maintenance in the past exploitation, required a more detailed study not only of the embankment along the route of the railway, but also of lithological members who are in the background or in the immediate environment. For this purpose were carried out specific field studies to the depth of basic soil, and perceived characteristics of the geological environment.

\section{Types and Scope of Research}

Research section is located in the northern part of Bosnia and Herzegovina or Republic of Srpska, and railway route extends from north to south along the right bank of the river Bosna, figure 1. The railway is on the higher bank of the river Bosna, and on the greater part of the route is higher, in relation to the river. All streams are on the right tributary of the river Bosna, and are mostly of torrential character. The catchment areas are forested, so erosion processes are not significantly expressed.

Along the the road route in the zone, width of about $100 \mathrm{~m}$, was carried out detailed engineering geological mapping, where were established lithological boundaries, thickness of lithological members, composition, assembly, genesis, history and deformation creation. Special attention was paid to the phenomena of instability, dredging areas and other similar phenomena in the field, which may be of importance for the reconstruction of the railway. On the terrain rock samples were taken for laboratory tests, for better identification of lithological members.

To determine the geotechnical characteristics of the embankment, 151 trial pits were made, depths of 0.7 to $>3.5 \mathrm{~m}$, depending from the morphology of the terrain. They were made laterally left and right, through the hull of the embankment, and perpendicular to the axle, through superstructure to the depth of subsoil, that is finished about $0.2 \mathrm{~m}$ in the primary rock. On all trial pits were taken 1 - 3 samples for laboratory tests on which were determined identifiable classifying and deformable resistant characteristics. Depending from the depth of embankment in every lithological change was made an experiment with dynamic board, total 273 experiments. Every trial pit was in detail photographed and mapped, figure 2. 


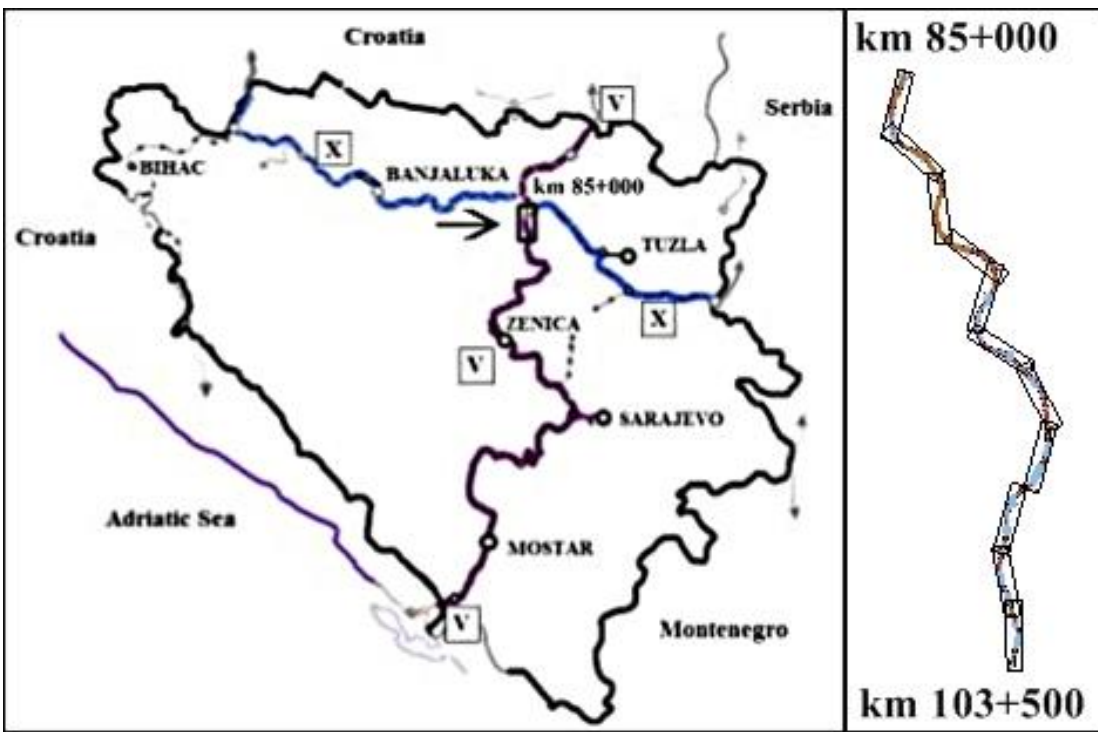

Figure 1: Position of researched section on the route of the railway, corridor $\mathrm{V}$.

\section{Detail Parsing of Lithological Members}

Wider environment of investigated area is made of coarse gravel - sandy material and fine grained clay dusty material with a significant participation of coarse grained fractions. The material is made of modern riverbed sediments, alluvial sediments of the river Bosna and river terrace sediments [1]. Based on the research terrain is generally built of quarternary sediments, which are represented by the following lithological members:

- embankment (n)

- modern sediments of riverbed (a)

- $\quad$ slope sediments, deluvial sediments (dl)

- proluvial sediments (pr)

- alevrolytes, clay, marls, sandstones and massive to layered limestones (Pc, E)

- layered limestones $\left(\mathrm{K}_{2}{ }^{2-3}\right)$

- coarse grained sandstones, marls and massive limestones (J, K)

- a complex of Jurassic sediments (J)

According to the degree of stability and suitability of terrain, stable, conditionally stable and unstable terrains were separated $[2,3,4]$. The distribution of lithological members along the route of the railway of research section and their main characteristics are shown in table 1.

Table 1: Distribution of lithological members along the railway route.

\begin{tabular}{|c|l|l|}
\hline Lithological members & \multicolumn{1}{|c|}{ Chainage } & \multicolumn{1}{c|}{ Main characteristics } \\
\hline \multirow{5}{*}{ Embankment $(\mathrm{n})$} & Along the route & $<2.0 \mathrm{~m}$ \\
& $\mathrm{~km} \mathrm{92+300-92+750}$ & $>3.0 \mathrm{~m}$ \\
& $\mathrm{~km} \mathrm{95+500-97+750}$ & $>3.0 \mathrm{~m}$ \\
& $\mathrm{~km} \mathrm{98+000-99+300}$ & $>3.0 \mathrm{~m}$ \\
& $\mathrm{~km} 101+500-102+100$ & $>3.0 \mathrm{~m}$ \\
\hline & $\mathrm{km} 86+250-87+280$ & They have good load capacity, high \\
& $\mathrm{km} 89+250-90+940$ & to low compressibility. In natural \\
\hline
\end{tabular}




\begin{tabular}{|c|c|c|}
\hline $\begin{array}{l}\text { Modern riverbed } \\
\text { sediments (a) }\end{array}$ & $\begin{array}{l}\mathrm{km} 93+000-93+400 \\
\mathrm{~km} 93+680-94+450 \\
\mathrm{~km} 97+900-98+330 \\
\mathrm{~km} 98+550-99+100 \\
\mathrm{~km} 99+140-99+300 \\
\mathrm{~km} 100+250-103+050\end{array}$ & $\begin{array}{l}\text { conditions are stable, as well as in } \\
\text { terms of construction. } \\
\text { Conditionally favorable for large } \\
\text { loads of shallower zones and for } \\
\text { deep cuttings }\end{array}$ \\
\hline \multirow[t]{4}{*}{$\begin{array}{l}\text { Slope sediments, } \\
\text { deluvial sediments (dl) }\end{array}$} & $\begin{array}{l}\mathrm{km} 87+880-88+670 \\
\mathrm{~km} 90+940-91+690 \\
\mathrm{~km} 96+100-96+470 \\
\mathrm{~km} 99+300-99+350 \\
\mathrm{~km} 102+160-102+210\end{array}$ & $\begin{array}{l}\text { In natural conditions are stable, } \\
\text { while in deeper cuttings and greater } \\
\text { load are unstable to conditionally } \\
\text { stable }\end{array}$ \\
\hline & $\begin{array}{l}\mathrm{km} 85+30-85+420 \\
\mathrm{~km} 85+620-85+730 \\
\mathrm{~km} 85+750-85+830 \\
\mathrm{~km} 86+080-86+280 \\
\mathrm{~km} 87+250-87+451 \\
\mathrm{~km} 88+230-88+600 \\
\mathrm{~km} 92+340-92+450 \\
\mathrm{~km} 95+500-95+750 \\
\mathrm{~km} 97+450-97+600 \\
\mathrm{~km} 98+780-99+00 \\
\mathrm{~km} 102+050-102+210\end{array}$ & $\begin{array}{l}\text { Unstable slope with thickness of } \\
\text { deluvial deposit up to } 2.0 \mathrm{~m} \\
\text { Unstable slope with thickness of } \\
\text { deluvial deposit up to } 2.0 \mathrm{~m}\end{array}$ \\
\hline & $\mathrm{km} 90+960-91+690$ & Unstable slope \\
\hline & $\begin{array}{l}\mathrm{km} 90+960-91+060 \\
\mathrm{~km} 91+160-91+500 \\
\mathrm{~km} 92+870-93+0,00 \\
\mathrm{~km} 103+460-103+500\end{array}$ & Active landslides \\
\hline Proluvial sediments (pr) & $\begin{array}{l}\mathrm{km} 85+225-85+350 \\
\mathrm{~km} 85+800-85+880 \\
\mathrm{~km} 86+075-86+150 \\
\mathrm{~km} 86+280-86+330 \\
\mathrm{~km} 87+250-87+880 \\
\mathrm{~km} 88+670-88+820 \\
\mathrm{~km} 88+850-89+170 \\
\mathrm{~km} 93+620-93+680 \\
\mathrm{~km} 95+040-95+090 \\
\mathrm{~km} 98+330-98+550 \\
\mathrm{~km} 100+380-100+600\end{array}$ & $\begin{array}{l}\text { In natural conditions are stable, and } \\
\text { conditionally stable and unstable } \\
\text { are at deeper cuttings and larger } \\
\text { loads }\end{array}$ \\
\hline \multirow[t]{2}{*}{ Alevrolytes (Pc,E) } & $\begin{array}{l}\mathrm{km} 91+690-92+300 \\
\mathrm{~km} 92+750-93+000 \\
\mathrm{~km} 93+400-93+620 \\
\mathrm{~km} 94+450-95+040 \\
\mathrm{~km} 95+090-95+300\end{array}$ & $\begin{array}{l}\text { In terms of construction, at kefs } \\
\text { and cuttings are stable, and in the } \\
\text { zones of enhanced karstification } \\
\text { are conditionally stable to unstable }\end{array}$ \\
\hline & $\mathrm{km} 91+790-91+900$ & Conditionally stable slope \\
\hline Layered limestones $\left(\mathrm{K}_{2}^{2-3}\right)$ & $\mathrm{km} 96+100-96+550$ & $\begin{array}{l}\text { In natural conditions are stable, and } \\
\text { in deep and steep cuts could be } \\
\text { conditionally stable }\end{array}$ \\
\hline $\begin{array}{l}\text { Coarse grained } \\
\text { marls and massive limestones } \\
(\mathrm{J}, \mathrm{K})\end{array}$ & $\mathrm{km} 97+180-97+300$ & Stable \\
\hline
\end{tabular}




\begin{tabular}{|l|l|l|}
\hline \multirow{4}{*}{$\begin{array}{l}\text { Complex of Jurassic sediments } \\
(\mathrm{J})\end{array}$} & $\mathrm{km} 85+000-89+180$ & \\
\cline { 2 - 3 } & $\mathrm{km} \mathrm{97+300-97+600}$ & Diabase chert formation \\
\cline { 2 - 3 } & $\mathrm{km} 97+600-97+900$ & \\
$\mathrm{~km} 99+100-99+140$ & Spilite, gabbro, serpentinite and \\
& $\mathrm{km} 99+350-100+250$ & peridotite \\
& $\mathrm{km} 102+210-103+500$ & \\
\hline
\end{tabular}

\section{Detail of Embarkment Parsing}

Materials that build an embankment along the vertical, ie superstructure and foundation of the railway, were established in exploratory trial pits, figure 2 , and have characteristics given in the table $2[5,6,7,8]$.
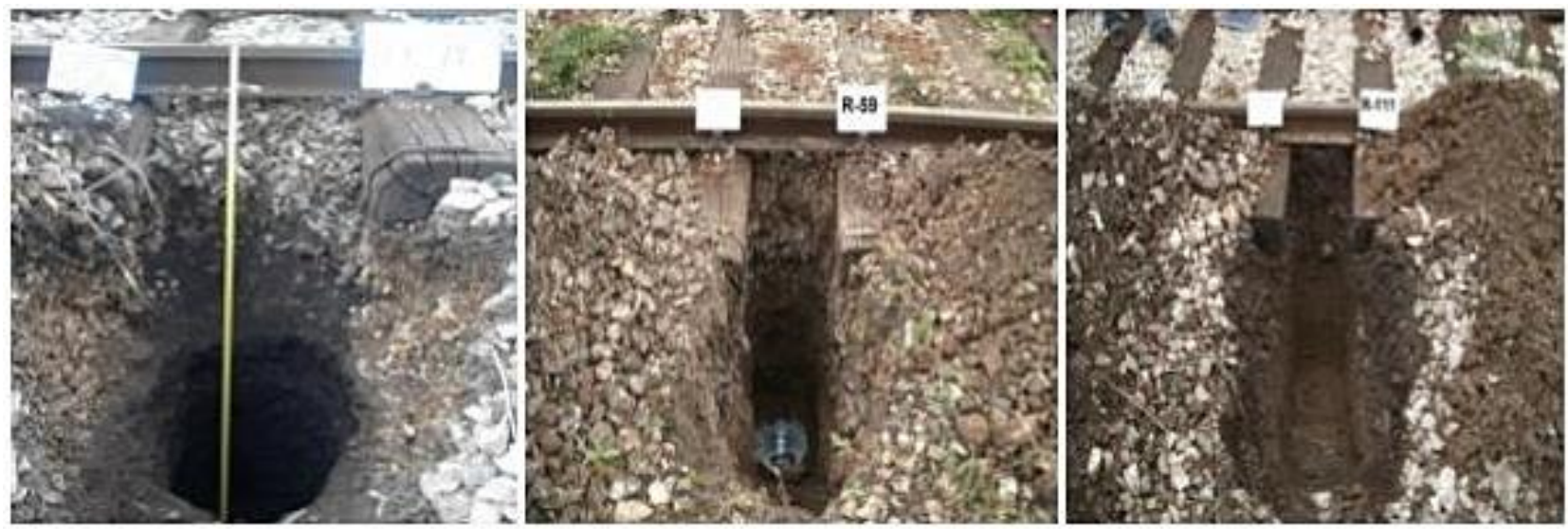

Figure 2: Characteristic trial pits along the research section of the railway route, corridor V.

Table 2: Characteristics of embankment along the railway route.

\section{Superstructure}

These include crushed stone surfacing of limestone debris, dirty, with traces of other materials, sizes $8.00-10.00 \mathrm{~cm}$. It has a relatively good physical - mechanical characteristics. Thickness of surfacing prism at examinatied chainages ranges from $0.20-1.50 \mathrm{~m}$. The dynamic deformation modulus $\left(\mathrm{MN} / \mathrm{m}^{2}\right)-\mathrm{Evd}=19.12-72.72, \mathrm{Ev}_{1}=18.32-71.36, \mathrm{Ev}_{2}=41.69-99.76$

\section{Foundation}

These include buffer zone and different mixtures of materials such as natural soil from material borrow pits. They are presented with dusty sandy clay, send and gravel from modern sediments, dusty sandy clay from deluvial sediments and dusty sandy clay from proluvial sediments.

\begin{tabular}{|c|c|c|}
\hline Type of layer & Characteristics & Description \\
\hline $\begin{array}{l}\text { Buffer layer } \\
\text { Buffer layer }\end{array}$ & $\begin{array}{ll}\text { - } & \text { grave }=151.2-71.8 \% \\
\text { - } & \text { sand }=26.7-40.3 \% \\
\text { - } & \text { dust }=0.8-7.1 \% \\
\text { - } & \text { clay }=0.4-1.9 \% \\
\text { - } & \text { Evd }=19.15-76.51\end{array}$ & $\begin{array}{l}\text { Sandy gravel, grain diameter corresponding to } \\
\text { the ordinate } 60 \%-\mathrm{d}_{60} \text { ranges from } 5.8115 \text { to } \\
10.43 \text {, grain diameter corresponding to the } \\
\text { ordinate } 10 \%-\mathrm{d}_{10} \text { ranges from } 0.0811 \text { to } 0.475 \text {. } \\
\text { Material built into buffer layer is the same in all } \\
\text { tested sections. Thickness by tested chainages }\end{array}$ \\
\hline
\end{tabular}




\begin{tabular}{|c|c|c|}
\hline & $\begin{array}{l}\text { - } \mathrm{Ev}_{1}=11.57-56.16 \mathrm{M} \\
\text { - } \mathrm{Ev}_{2}=19.120-89.80\end{array}$ & $\begin{array}{l}\text { range from } 0.05-0.69 \mathrm{~m} \text {, or there is no buffer } \\
\text { layer. }\end{array}$ \\
\hline Dusty sandy clay & $\begin{array}{ll}- & \text { Sand }=04.8-12.2 \% \\
\text { - } & \text { dust }=72.7-81.7 \% \\
\text { - } & \text { gravel }=13.1-14.9 \% \\
\text { - } & \text { natural moisture } \\
& \omega=23.12-29.34 \% \\
\text { - } & \text { optimum moisture by } \\
& \text { Proctor-u } \omega_{\text {opt. }}=13.7 \% \\
\text { - } & \text { plastic limit } \\
& \omega_{\mathrm{p}}=18.3-21.4 \% \\
\text { - } & \text { plasticity index } \\
& \mathrm{I}_{\mathrm{p}}=25.4-36.2 \% \\
\text { - } & \mathrm{CBR}=15.9 \% \\
\text { - } & \mathrm{Evd}=13.50-67.78 \\
\text { - } & \mathrm{Ev}_{1}=12.10-63.21 \\
\text { - } & \mathrm{Ev}_{2}=19.803-98.15\end{array}$ & $\begin{array}{l}\text { Natural soil of modern sediments from material } \\
\text { borrow pits medium hard to hard clay, } \\
\text { compressible, low plastic. }\end{array}$ \\
\hline Dusty sand & $\begin{array}{ll}\text { - } & \text { gravel }=3.11 \% \\
\text { - } & \text { sand }=69.99 \% \\
\text { - } & \text { dust }=21.89 \% \\
\text { - } & \text { clay }=5.01 \% \\
\text { - } & \text { natural moisture } \\
& \omega=30.76 \% \\
\text { - } & \mathrm{Evd}=12.42-63.88 \\
\text { - } & \mathrm{Ev}_{1}=11.87-62.51 \\
\text { - } & \mathrm{Ev}_{2}=19.98-99.17\end{array}$ & $\begin{array}{l}\text { Natural soil of modern sediments from the } \\
\text { material borrow pits, very little compressible. }\end{array}$ \\
\hline Sandy gravel & $\begin{array}{ll}\text { - } & \text { gravel }=65.47 \% \\
\text { - } & \text { sand }=29.52 \% \\
\text { - } & \text { dust }=3.56 \% \\
\text { - } & \text { clay }=1.45 \% \\
\text { - } & \text { natural moisture } \\
& \omega=7.68 \% \\
\text { - } & \mathrm{Evd}=13.33-51.11 \\
\text { - } & \mathrm{Ev}_{1}=12.67-63.52 \\
& \mathrm{Ev}_{2}=18.14-95.14\end{array}$ & $\begin{array}{l}\text { Natural soil of modern sediments from the } \\
\text { material borrow pits, very little compressible. }\end{array}$ \\
\hline Basic soil - rock & & $\begin{array}{l}\text { Natural soil - liological members given by } \\
\text { chainages in table } 1 \text {. }\end{array}$ \\
\hline
\end{tabular}

\section{Discussion}

The importance of the railway demanded a detailed research of lithologic members and buffer layer along the route of the railway. Detail started on the terrain, where were extracted all litological changes and character of the slope in terms of stability. Also on carried researched trial pits in detail were realized characteristics of embankment and the level of its demage along the railway route. Besides presented data, during the research were registered all damages with the same level of detail. 
The samples taken in the field from lithological members and buffer layer for laboratory tests, and carried experiments with a dynamic circular plate in trial pits, enabled the complete definition of the characteristics of lithologic members and buffer embankment.

In general the research section requires revitalization as a whole, given that the conditions required the speed of trains up to $120 \mathrm{~km} / \mathrm{h}$. Track constructed 60 years ago requires the construction of a new buffer layer, not because of its bad characteristics, but because of the new regulations that requires modern way of construction.

Replacing materials or setting up an entirely new material in the buffer layer requires its compaction to the requested value $\mathrm{E}_{\mathrm{vd}}$. Range depending on the part of the buffer layer $30 \mathrm{MN} /$ $\mathrm{m} 2$ in embankment hull to $>55 \mathrm{MN} / \mathrm{m}^{2}$ at railway planum. In the part where is needed a replacement of subsoil as a natural terrain, should be made with the material where can be achieved $\mathrm{E}_{\mathrm{vd}} \geq 25-30 \mathrm{MN} / \mathrm{m}^{2}$.

\section{References}

[1] Laušević, M., Jovanović, Č., Mojičević, M. Basic geological map of Yugoslavia, sheet Doboj, R 1: 100000, and OGC interpreter. Federal Geological Institute, Belgrade, Serbia, 1980.

[2] Đurić, N. Hidrogeološka i inženjersko-geološka istraživanja. Građevinski fakultet Subotica, Srbija i Tehnički institut Bijeljina, Bosna i Hercegovina, 2011.

[3] Group of authors. The program engineering geological, hydrogeological and geotechnical investigation works for the section of the highway corridor Vc, Doboj Jug. IPSA Sarajevo. Fond of professional documents IPSA Sarajevo, Technical Institute Bijeljina, Bosnia and Herzegovina, 2012.

[4] Project: WB5-BH-TRA-14. The main repair services stripes section Doboj - Maglaj and Jelina Zenica on Corridor Vc PHASE II: Main project, section Doboj - km $103+500$ th Book 4. Geological - geotechnical study. Technical Institute, Bijeljina, Bosnia and Herzegovina, 2013.

[5] Ćulibrk, S. R. Geotehnički radovi u niskogradnji. Građevinski fakultet Subotica, Rudarskogeološki fakultet Beograd, Srbija, 1996.

[6] Najdanović, N., Obradović, R. Mehanika tla u inženjerskoj praksi. Beograd, Rudarski institut, Beograd, Srbija, 1979.

[7] Bowles, J. Fondation analysis and desing. Exoloration, sampling and in situ soil measurements. Fifth edition. McGraw Hill Higher Education, 1997.

[8] Eurocode 7. Geotechnical desing - Part 2: Desing assisted by laboratory testing and Part 3: Desing assisted by fieldtesting. European Commitete for standarization.

*Corresponding author.

E-mail address: nedjo@ tehnicki-institut.com 